\title{
Setting Maritime Limits and Boundaries: Experiences from Norway
}

\author{
Harald Brekke
}

\section{1 \\ Introduction}

Part VI of the 1982 UN Convention on the Law of the Sea (UNCLOS, the Convention) deals with the regime of the continental shelf of coastal states. Article 77 provides for the rights of the coastal state over the continental shelf, while Article 76 provides for the limits of that shelf. The coastal state has the obligation to delineate and establish those limits in accordance with Article 76 and Annex II of the Convention. Until now, 72 coastal states have made submissions in this respect. The background, principles and practical work involved in this procedure are described in this chapter.

After a review of the main delineation principles currently applied in order to determine maritime jurisdiction of the coastal state over the seabed, as defined in UNCLOS and interpreted by the courts (Section 2), the chapter continues by reviewing the Norwegian experiences with setting the country's maritime boundaries, as a concrete application of the principles identified. The elements related to the organisation of the work for the purpose of submissions to the Commission on the Limits of the Continental Shelf (CLCS) (Section 3), the mapping the outer limits (Section 4) and to the cooperation with neighbouring states (Section 5 ) are successively analysed. The chapter ends with an overview of the currently identified resources on the Norwegian continental shelf (Section 6).

In the 1958 Geneva Convention, the limit of the jurisdiction over the seabed, i.e. the continental shelf, is made dependent on exploitability so that it may extend 'to where the depth of the superjacent water admits of the exploitation 
of the natural resources.' ${ }^{1}$ As technology developed in the 196os, this criterion turned out not to imply any limit at all. Therefore, states agreed on provisions in the Convention for the precise definition and establishment of continental shelf limits as 'final and binding.'

The agreement, however, is not about the specific limits for each state, but an agreement on the set of rules and provisions on how these limits are to be measured and generated. As regards the Territorial Sea, Contiguous Zone and the Exclusive Economic Zone (EEZ), their limits are generated directly from the coastal baselines of the coastal States. ${ }^{3}$ The limits of the continental shelf beyond 200 nautical miles $(\mathrm{nm})$ are different because they are not measured from the baselines.

The extent of the continental shelf of a coastal state is defined in Article 76 of the Convention. The principles of Article 76 are founded on the distinction between the terms the continental shelf and the continental margin. Both terms are defined in Article 76 for the purpose of the Convention by incorporating both legal and scientific aspects.

In geo-science, the continental margin is generally understood to be the submerged prolongation of the continent and is defined as the area of seafloor between the coast of a continent and the plains of the deep ocean floor at generally 4,000-6,000 meters $(\mathrm{m})$ depth. Most definitions of the continental margin are based on the widely accepted morphological subdivision of its seabed into the continental shelf, the continental slope and the continental rise. In this context, the continental shelf is the relatively shallow seabed area (100$400 \mathrm{~m}$ depth) adjacent to the coast and landward of the continental slope.

Paragraph 1 of Article 76, however, defines the continental shelf of a coastal State as the seabed areas that extend beyond the territorial sea throughout the natural prolongation of the coastal State's land territory. Being a natural prolongation of the territory implies that, for the purposes of the Convention, the term the continental shelf is a juridical term meaning the seabed areas over which the coastal State has jurisdiction. Furthermore, Article 76 provides that this juridical continental shelf may extend up to the outer edge of the continental margin (or to $200 \mathrm{~nm}$, whichever is the farther). That is, the continental shelf in its juridical sense may encompass the whole continental margin and not only its inner, shallow parts as in its scientific sense. In this way, the

1 United Nations Treaty Series No. 7302, vol. 499, pp. 312-321; Convention on the Continental Shelf. Done at Geneva, on 29 April 1958, Article 1.

2 UNCLOS, Article 76, paragraph 8.

3 'Norwegian Baselines, Maritime Boundaries and the UN Convention on the Law of the Sea', B.G. Harsson and G. Preiss, Arctic Review on Law and Politics, vol. 3, 1/2012 p. 108-129. ISSN $1891-6252$. 
Convention is using the concept of the continental margin as a means of measuring and delineating the limits to the prolongation of the continental shelf.

To this end, the Convention has introduced its own conceptual definition of the continental margin. Paragraph 3 of Article 76 states that:

The continental margin comprises the submerged prolongation of the land mass of the coastal State, and consists of the sea-bed and subsoil of the shelf, the slope and the rise. It does not include the deep ocean floor with its oceanic ridges or the subsoil thereof.

In this definition, the starting point of the continental margin is not a continent as such, but the land mass of a coastal State, either it be hosted in a continent or in an oceanic island. This implies that the existence of a State is a prerequisite for the existence of a continental margin for the purposes of the Convention. Thus, paragraph 3 links the term the continental margin to the jurisdiction of a State but still incorporates elements that have kept their scientific, geological and morphological meaning, i.e. land mass, shelf, slope and rise.

Being the yardstick for the extent of the continental shelf, the submerged prolongation of the continental margin determines the natural prolongation of the land territory of a coastal State as referred to in paragraph 1 of Article 76. Paragraph 4 of Article 76, gives the operational definition for the outer edge of the continental margin for the purposes of the Convention. According to this paragraph, the outer edge of the continental margin is to be established at a certain distance from the foot of the continental slope by either of two methods: the Hedberg rule, or the Gardiner rule (Figure 4.1). This must imply that the natural prolongation referred to in paragraph 1 is not a separate property of the continental shelf itself but emanates from the application of paragraph 4.

This understanding is also supported by the International Tribunal of the Law of the Sea (ITLOS, the Tribunal) in the case between Bangladesh and Myanmar. 4 (That case also illustrated that the principles involved in the delineation of the outer limits of the continental shelf may be brought into a dispute on the delimitation between states. ${ }^{5}$ ) In its decision on the case, the Tribunal

4 International Tribunal for the Law of the Sea, 2012; Case No. 16, Dispute Concerning Delimitation of the Maritime Boundary between Bangladesh and Myanmar in the Bay of Bengal, adopted 14 March 2012.

5 C. Schofield, 'One step forwards, two steps back? Progress and challenges in the delimitation of maritime boundaries since the drafting of the United Nations Convention on the Law of the Sea' in G. Xue and A. White (ed), 30 Years of UnCLOS (1982-2012): Progress and Prospects (2013) 217-239. 


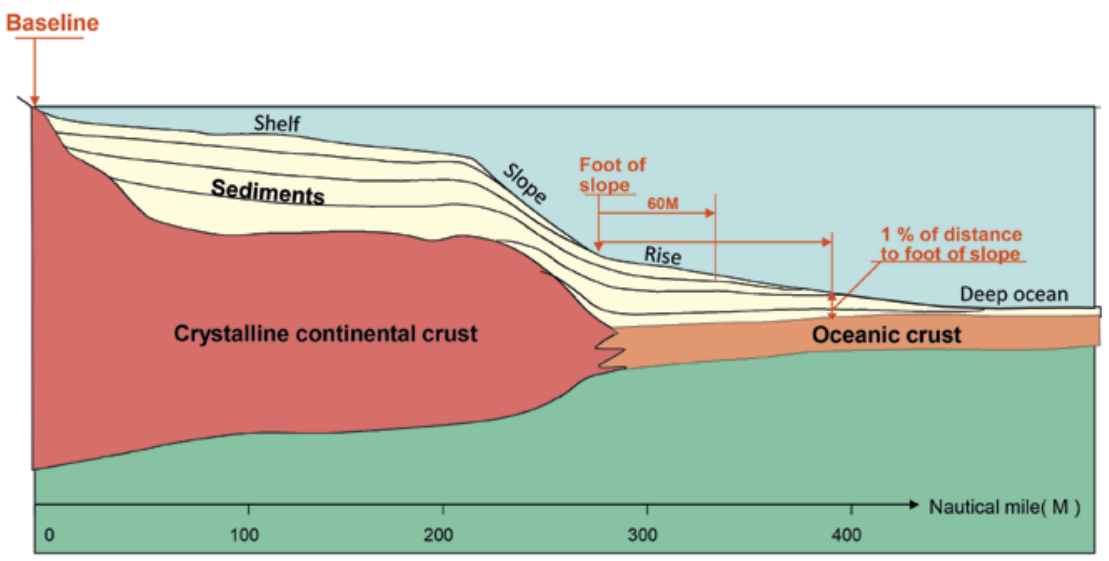

FIGURE 4.1 Schematic profile of the continental margin with geological terms in black and delineation terms of Article 76 in red. According to Article 76, the outer edge of the continental margin is to be set at a distance of either $60 \mathrm{~nm}$ from the foot of the slope (the Hedberg Rule) or at a location where the sediment thickness is not less than $1 \%$ of the distance to the floor of the slope (the Gardiner Rule) THE NORWEGIAN PETROLEUM DIRECTORATE

spells out their view on the question of the natural prolongation in paragraphs 433 to 437 and concludes as follows:

437. For these reasons, the Tribunal is of the view that the reference to natural prolongation in article 76 , paragraph 1 , of the Convention, should be understood in light of the subsequent provisions of the article defining the continental shelf and the continental margin. Entitlement to a continental shelf beyond $200 \mathrm{~nm}$ should thus be determined by reference to the outer edge of the continental margin, to be ascertained in accordance with article 76 , paragraph 4 . To interpret otherwise is warranted neither by the text of article 76 nor by its object and purpose.

Thus, the application of Article 76 , paragraph 4 is the basis for defining the outer edge of the continental margin and thereby identifying the entitlement to a continental shelf beyond $200 \mathrm{~nm}$. Hence, the location of the foot of the continental slope is the critical factor, both for the entitlement to, and extent of, the continental shelf of a State.

Identifying the outer edge of the continental margin by such measurements deviate from the common geoscientific concept of the margin but has the advantage of defining a precise location of its outer edge. A coastal State may apply the two methods to suit its own interest, i.e. by applying only one, or alternating between the two, along its continental margin in order to establish 
the outer limits of its continental shelf beyond 200 nautical miles. A coastal State that intends to establish such limits, must submit the particulars of these limits to the Commission on the Limits of the Continental Shelf (CLCS, the Commission) along with supporting scientific and technical data. ${ }^{6}$

In order to apply the provisions and methods given in Article 76 , the coastal State needs certain geophysical, geological and geodetic ${ }^{7}$ data covering the critical parts of its continental margin. Bathymetric data is needed to map the topography of the seafloor and to identify the foot of the continental slope. Seismic data is needed to determine the thickness and, sometimes, the nature of sediments of the sub-surface. In many cases, geological data is required to characterize important seafloor features like submarine ridges and elevations. Geodetic methods and data are required to calculate the appropriate distances and construct the final limits. The acquisition and use of these data requires the expertise of geophysicists, geologists and hydrographers. This is also the reason why the Convention stipulates that the members of the Commission shall be experts in one of these fields.

The Commission gives recommendations to each coastal state separately on the location of outer limits of the continental shelf as it may be established according to Article 76 , without regard to the outer limits of the continental shelf of neighbouring states. In several cases, this leads to areas of overlapping continental shelf of states with adjacent or opposite coasts. The settling of bilateral boundaries in such cases is up to the states involved only. ${ }^{8}$ The final and binding limits of the continental shelf enters into force when their particulars are deposited with the Secretary-General of the UN and/or the Secretary General of the International Seabed Authority. ${ }^{9}$

\section{3}

\section{Norway's Work with the Submissions to the CLCS}

\subsection{Norwegian Organization of Work}

Norway signed the Convention on the day it was opened for signature and ratified it on 24 June 1996. It entered into force in Norway on 24 July 1996. The same year, the Norwegian Foreign Ministry initiated the work related to

6 UNCLOS, Article 76, paragraph 8, and Annex II, article 4.

7 Geodetic data means the formally correct data and information that are needed to produce a map, including datum, projection, coordinates and distance calculations.

8 unClos, Article 83. See on that point M.D. Evans, 'Maritime Boundary Delimitation' in D. Rothwell, A. Oude Elferink, K. Scott and T. Stephens, 'The Oxford Handbook of The Law of the Sea' (Oxford, 2015), chapter 12, pp. 254-279.

9 UNCLOS, Article 76, paragraph 9, and Article 84. 
the establishment the outer limits of the continental shelf of Norway beyond $200 \mathrm{~nm}$ in accordance with Article 76 and Annex II of the Convention.

The particulars of these limits along with supporting scientific and technical data were organized in two partial submissions to the Commission. The first submission was made on 27 November 2006 in respect of areas in the Arctic Ocean, the Barents Sea and the Norwegian Sea. The second submission was made on 4 May 2009 in respect of areas in the South Atlantic Ocean adjacent to the Bouvet Island, and the Southern Ocean adjacent to Dronning Maud Land in Antarctica.

Each submissions consisted of three parts as prescribed in the Scientific and Technical Guidelines of the Commission, i.e. an Executive Summary, a Main Body, and a third part with all the supporting scientific and technical data. ${ }^{10}$ The Executive Summary was posted on the CLCS website ${ }^{11}$ and contained a short description of the different parts of the continental shelf beyond 200 $\mathrm{nm}$, charts and list of coordinates defining their outer limits, references to the provisions of Article 76 invoked, and a status of any delimitations matters with neighbouring states. The Main Body contained a detailed description of the hydrography and geology of the relevant continental margins, and the technical procedures and scientific methodologies applied in the implementation of Article 76 to delineate the continental margin. The results were presented by maps and coordinates and documented by all relevant data. The third part contained a copy of all data and computer-based analyses (e.g. GIS projects) referred to in the main body.

The submissions were prepared under the direction of the Norwegian Ministry of Foreign Affairs. The Norwegian Petroleum Directorate (NPD, the Directorate), an independent agency under the Ministry of Petroleum and Energy (MPE), was the technical coordinator and carried out the technical preparation of the submissions. The Directorate is Norway's expert body for offshore geology and geophysics. For the specific needs of the project, the NPD carried out an extensive marine programme for acquiring geophysical and geological data. These data were in general interpreted and analysed by the NPD. In addition, the data were made available to various other national agencies and institutions, including the Norwegian Mapping Agency, the Universities of Bergen, Oslo and Tromsø, and the Norwegian Polar Institute, which also made scientific and other contributions to the preparations of the submissions.

\footnotetext{
10 CLCS/11 The Scientific and Technical Guidelines of the Commission on the Limits of the Continental Shelf, paragraphs 9.1.4, 9.1.5 and 9.1.6.

11 Document available at: <http://www.un.org/Depts/los/clcs_new/clcs_home.htm>.
} 
The NPD also established technical cooperation programmes with their peer institutions of the neighbouring coastal states with which Norway would have overlapping continental shelf areas beyond $200 \mathrm{~nm}$, i.e. Russia, Iceland and Denmark with Greenland and the Faroe Islands. The cooperation included data exchange and joint mapping programmes. All of these activities were funded by the Government through the NPD.

\subsection{Commission Procedures and Recommendations regarding the Submission of 27 November 2006}

On 2 April 2007, the Commission established a sub-commission of seven of its members to examine and consider the details of the submission made by Norway. During the next two-year period, Norway provided clarifications and further data and information on request by the Sub-commission, made written responses to its preliminary considerations, and met regularly twice a year with the Sub-commission in New York. The Norwegian delegation was headed by the Ministry of Foreign Affairs with the NPD as technical assistant on a permanent basis. Experts from universities and the National Mapping Agency were included as needed. The Department of Geosciences at the University of Oslo was represented on an almost permanent basis because of their involvement in the previous joint Norwegian-Russian cooperation projects. During the two years of interaction with the Sub-Commission, Norway provided 34 documents with annexes, 25 PowerPoint presentations, and $31 \mathrm{CD} / \mathrm{DVD}$ with supplementary information and data. On 13 March 2009, the sub-commission submitted its recommendations to the plenary of the Commission.

On 27 March 2009, the Commission adopted its recommendations concerning the Norwegian submission. The Commission agreed with the outer limits as submitted by Norway, except for recommending a minor reduction of area in the Norwegian Sea and a slight increase in the Nansen Basin in the Arctic Ocean (see Figure 4.2).

\subsection{Commission Procedures and Recommendations regarding the Submission of 4 May 2009}

In accordance with the request of Norway, ${ }^{12}$ with reference to the Antarctic Treaty System as explained below, the Commission decided not to take any

12 Document available at: <https://www.un.org/Depts/los/clcs_new/submissions_files/ nor30_09/nor20o9_executivesummary.pdf>. 
action on the part of the submission that related to the continental shelf appurtenant to Antarctica, i.e. the areas appurtenant to Dronning Maud Land. ${ }^{13}$

For the parts of the submission concerning the continental shelf appurtenant to the Bouvet Island in the South Atlantic Ocean, the Commission established a sub-commission of seven members at its 32nd session in August 2013. During the next three-year period, Norway provided further data and information on request by the Sub-commission, made written responses to its preliminary considerations, and met regularly thrice a year with the Sub-commission in New York. Again, the Norwegian delegation was headed by the Ministry of Foreign Affairs with the NPD as technical assistant on a permanent basis. Experts of the Department of Geosciences at the University of Oslo were represented on an almost permanent basis because of their expertise in geophysical modelling.

Norway was of the opinion that since the time the submission was made in 2009, the practice of the Commission had evolved in a way that made it relevant for Norway to revise the outer limits of the continental shelf in the area appurtenant to the Bouvet Island.

Norway agreed with the Sub-commission that the amendment of the outer limits proposed by Norway required the submission of a revised Executive Summary to be posted on the website of the Commission. Accordingly, Norway submitted a revised Executive Summary on 21 May 2015 that was posted on the website the same day. On the request of the Sub-commission, Norway collected and made available supplementary data to support the revised limits.

Based on all the data thus made available, the Sub-commission agreed with the revised outer limits as submitted by Norway and adopted its recommendations to this effect on 11 August 2016. The Sub-commission subsequently submitted its recommendations for the Commission's 41st plenary session during which Norway delivered its final presentation to the Commission on 16 August 2016. However, the term of the Commission members ended in June 2017 and the Meeting of States Parties elected members for the next fiveyear term on 14 June 2017. The consideration of the recommendations of the Sub-commission was then passed on to this new set of members. On request, Norway was given the opportunity to repeat its final presentation to the new Commission members on 7 August 2018.

On 8 February 2019, the Commission adopted its recommendations to Norway concerning the outer limits of the continental shelf in the area

13 Brekke, H. 2014. Defining and recognizing the outer limits of the continental shelf in the polar regions. In: R. Powell and K. Dodd (Editors), Polar Geopolitics? Knowledges, Resources and Legal Regimes. Edward Elgar Publishing Ltd., Celtenham, UK; Northampton, MA, USA.: $3^{8-54}$. 
appurtenant to the Bouvet Island. The Commission agreed with the outer limits as submitted by Norway, with minor changes.

The sub-commissions for the two submissions carried out very thorough examinations of the substantial amount of data and information submitted. The role of the Norwegian delegation was essentially to give assistance to the sub-commissions in their examinations by providing clarifications and supporting data. The sub-commissions put much of their time and work into satisfying themselves that the foot of the slope points were correctly defined and adequately documented. In this respect, the recommendations issued for the areas of the Arctic Ocean, the Barents Sea and the Norwegian Sea established a precedence for how to define the location of the foot of very low gradient continental slopes of sedimentary origin. The Sub-commission for the areas of the South Atlantic Ocean, put much emphasis also on satisfying itself that it could support the principle applied for the maximum constraint of the continental self. The recommendation on the area in the South Atlantic Ocean may become an important reference regarding the submerged prolongation of the landmass of oceanic islands and their maximum outer limits. The Norwegian delegation was dedicated to meeting the concerns of the subcommissions with responses that would instil confidence in the basis for the recommendations on the final outer limits. States

The technical work of the NPD consisted of four parts:

1. NPDs data acquisition program;

2. Data acquisition in cooperation with academic and peer government institutions;

3. NPD scientific cooperation with academic institutions and neighbour state's peer government institutions;

4. NPD analyses, compilation of all data and information, and preparation of final submission documents and supplementary material.

The technical work covered areas of continental shelf beyond $200 \mathrm{~nm}$ in five different oceans and seas (See Figure 4.2):

- The Barents Sea, in the area enclosed by the 200 nautical mile limits of Norway and Russia, also known as the 'Loop Hole';

- The Arctic Ocean, in an area north of Svalbard known as the 'Nansen Basin';

- The Norwegian Sea, in the area enclosed by the $200 \mathrm{~nm}$ limits of Norway, Iceland and Denmark with the Faroe Islands and Greenland, also referred to as the 'Banana Hole'; 
- The South Atlantic Ocean, in the area around the Bouvet Island in the South Atlantic;

- The Southern Ocean, in the area north of Dronning Maud Land in Antarctica. The work progress and the conclusions reached for each for those five areas are reviewed successively in the sections below.

\subsection{The Barents Sea}

The Barents Sea is a vast shallow water shelf area situated north of mainland Norway and Russia, bounded in the east by Novaya Zemlya and the Kara Sea, and in the north and west by the archipelagos of Franz Josef Land and Svalbard and the deep waters of the Norwegian and Greenland Seas. The 'Loop Hole' is an area beyond, and entirely enclosed by, the $200 \mathrm{~nm}$ limits of Norway and Russia. This area forms part of the shallow waters of the Barents Sea, and all of it is situated landward of the foot of the continental slope and the 2,500 $\mathrm{m}$ isobath. With reference to the applicable rules in Article 76, paragraphs 3-5, of the Convention, Norway submitted that the area may be considered to be part of the continental shelf and that there was no need for further scientific or technical documentation.

\subsection{The Arctic Ocean}

The Arctic Ocean is enclosed by the shallow shelf areas of the five Arctic states: Canada, United States of America (USA), Russia, Norway, and Denmark with Greenland. A central topographic element of the Arctic Ocean is the submerged Lomonosov Ridge that extends right across the ocean between the Greenland and Siberian shelves. This ridge divides the ocean into two parts, the complex Amerasian Basin on the American side and the oceanic Eurasian Basin on the other. The Eurasian Basin in turn, is subdivided into the Amundsen Basin to the north and the Nansen Basin to the south.

The northward extension of the shallow shelf areas of the Barents and Kara Seas ends at the continental slope along the Nansen Basin. In the continental margin in the western part of this basin, north of the archipelagos of Svalbard and Franz Josef Land, it was clear that Norway and Russia would have overlapping areas of continental shelf. Thus, the two states agreed that it was in the interest of both to cooperate in the mapping and delineation of the outer limit of the continental shelf in this region. Accordingly, the NPD and its peer Russian institute, the All-Russia Research Institute of Geology and Mineral Resources of the World Ocean (VNIIOkeangeologia) in St. Petersburg entered into a joint research project in this regard. Besides the scientific results, the main purpose of the project was to establish a common view of the location 
of the outer limits of the continental shelf in the region and to provide the required supporting data and information needed by the two states to prepare their submissions to the Commission. For the purposes of the submissions, the project started in 1996 and ended in 2006. For scientific purposes, however, this cooperation between Norway and Russia has continued since.

The project included data exchange and the establishment of a common database of existing data. To cover gaps in the database, Norway in 2001 and 2005 acquired an additional 1,000 km of seismic and $2500 \mathrm{~km}$ of bathymetric data with the Swedish icebreaker 'Oden' and with the assistance of experts from the University of Bergen. All the data finally available, the analyses thereof, and results of the joint Norwegian/Russian research, formed the basis for the Norwegian submission in this region.

\subsection{The Norwegian Sea}

The Norwegian Sea is the part of the North Atlantic Ocean west of the coast of Norway between $\operatorname{Stad}\left(62^{\circ} \mathrm{N}\right)$ and Senja $\left(70^{\circ} \mathrm{N}\right)$. To the west, it is bordered by the Greenland Sea along a submarine ridge system running from Iceland, via Jan Mayen to Bear Island. To the south, it is bordered by the North Sea and a submarine ridge connecting the Faroe Islands and Iceland. To the north, it is bordered by the shallow shelf areas of the Barents Sea.

Norway's continental margins in this region comprise two parts. One part is constituted by the continental margin of mainland Norway and the Svalbard archipelago. It extends from the North Sea in the south, through the Norwegian and Greenland Seas, and into the Arctic Ocean. The other part is the continental margin surrounding the island of Jan Mayen. The two parts face each other with the area beyond $200 \mathrm{~nm}$, the 'Banana Hole', located in the middle.

This area comprised the potentially largest area of continental shelf beyond $200 \mathrm{~nm}$ of Norway in the northern hemisphere. The shallow shelf areas within $200 \mathrm{~nm}$ in this region was geologically well known because it had been subject to extensive exploration for, and exploitation of, oil and gas since the late 1970s. The deep ocean within the 'Banana Hole', however, needed a closer study in order to establish the outer limits of the continental shelf. Therefore, the NPD carried out three major marine campaigns on tender to acquire sufficient data for the purpose of the submission. This amounted to $10,500 \mathrm{~km}$ of seismic data and $270,000 \mathrm{~km}^{2}$ of multi-beam bathymetric data. It was clear that in the southern part of the Banana Hole there would be a potential overlap with the continental shelf of Iceland and Denmark with the Faroe Islands. From the start, there was communication between the three states on both diplomatic and technical level. At the technical level, the NPD engaged in a 
data exchange programme and professional discussions with its peer institutions, the Faroese Earth and Energy Directorate (Jarðfeingi) of Denmark, and Iceland GeoSurvey (ISOR) of Iceland.

\subsection{The South Atlantic Ocean}

The Bouvet Island is located around $54^{\circ} \mathrm{S}, 4^{\circ} \mathrm{E}$. The submerged prolongation of the landmass of the island consists of a wide submarine elevation that narrows north-eastwards into a long spur. The outer limits of the continental shelf beyond 200 nautical miles from the baseline, which are based on this submarine elevation extends north-eastwards to about $50^{\circ} \mathrm{N}, 15^{\circ} \mathrm{E}$. The baseline of the Bouvet Island was established by Royal Decree of 25 February 2005, and deposited with the Secretary-General on 31 March the same year. The original submission in respect of the Bouvet Island was based mainly on publicly available data derived from previous Norwegian and international scientific expeditions.

However, in regard of the revision of the submission described in section 3.3, Norway carried out a new marine acquisition survey to provide further bathymetric data in critical parts of the area. This survey was carried out by the Norwegian Polar Institute in January 2014. In order to acquire further supplementary data as requested by the Sub-commission, Norway engaged the Russian State Research Navigation-Hydrographic Institute (GNINGI) to carry out an expedition to gather multi-beam bathymetric data and seabed rock samples for geochemical studies. For this purpose, GNINGI made available the research vessel R/V Akademik Fedorov during its annual visit to Antarctic waters in March 2016, and with VNIIOkeangeologia as operator for the rock sampling. The expedition resulted in the acquisition of 3,200 line $\mathrm{km}$ of MBES data, including an area of $8350 \mathrm{~km}^{2}$ full coverage, and 88 rock samples by dredging.

\subsection{The Southern Ocean}

The Southern Ocean is the area of seas south of $60^{\circ} \mathrm{S}$ surrounding the Antarctic Continent. Within this ocean, the continental margin appurtenant to Dronning Maud Land extends beyond 200 nautical miles as measured from relevant basepoints established by Norway along the coastline of the land area. The seafloor of the continental margin in this area includes several large elevations and ridges. In order to establish a reliable outline of the outer edge of this continental margin in accordance with the provisions of article 76 , Norway had to acquire more data. The whole area of the Southern Ocean is subject to the Antarctic Treaty System, and Norway recognized that any data acquisition 
should serve scientific purposes. In order to achieve this, Norway financed a three-year joint scientific program between the University of Bergen and the two research institutes VNIIOkeangeologia and PMGRE in St. Petersburg. The latter made available the research vessel R/V Akademik Karpinsky, which on an annual basis visit Antarctic waters, for acquiring bathymetric and seismic data. In addition, Norway also funded a data acquisition cruise with the Norwegian research vessel R/V G.O. Sars in the area. It all added up to 8000 $\mathrm{km}$ of seismic data and 9000 line $\mathrm{km}$ of multi-beam bathymetry data. The data acquired became the basis for several Master and $\mathrm{PhD}$ degrees and scientific publications. All data from the Southern Ocean have been submitted to the database of the Scientific Committee on Antarctic Research (SCAR).

Upon receiving the submission from a coastal state, the Commission publishes the executive summary of the submission on its website. ${ }^{14}$ A period of at least three months is then allowed for comments by other states before the Commission puts that submission on its agenda. This website has become a forum in which states make known their statements and views on the submissions of other states and any other related issues, in the form of notes verbale.

The submission that Norway made in respect of the Arctic Ocean, the Barents Sea and the Norwegian Seas implied actual and potential overlaps with the continental shelf limits of the neighbour states, Russia, Iceland and Denmark with Greenland and the Faroe Islands.

\subsection{Relationship with Russia}

Russia had made its first submission in 2001, in which it submitted a sector line as the western limit of the continental shelf in the Barents Sea and western Nansen Basin. This included almost the entire Loop Hole. Norway submitted the median line with Russia as its eastern limit of the continental shelf. Thus, there was an area of overlapping continental shelf area throughout the Barents Sea and into the Nansen Basin in the north. This overlapping area was not new to the two states; Norway and Russia had been negotiating their bilateral, marine boundary in this area since 1971. By mutual notes verbale, the two states made it clear that their continental shelf submissions did not prejudice anything in these negotiations.

14 Website of the CLCs: <www.un.org/Depts/los/clcs_new/clcs_home.htm $>$. 
Following the submission by Russia in 2001, Norway submitted a note verbale to be posted on the website of the Commission. By this, Norway referred to the unresolved delimitation issue with Russia and specified the area under negotiations by giving the coordinates of each of the two state's positions. Norway, with reference to paragraph 5 of Annex I of the Rules of the Procedure of the Commission, declared that it had no objections to the Commission considering and making recommendations with regard to the Russian submission as these recommendations would not prejudice the future delimitation between the two states (now customary known as a note verbale of non-objection). ${ }^{15}$

Following the submission by Norway in 2006, Russia submitted a similar note verbale of non-objection with regard to Norway. The wording of the two notes verbale are identical, except for comments on details regarding coordinates, confirming prior, close consultations regarding these notes. In its note, Russia also made the reservations that the note itself should not prejudice the position of Russia 'towards the Spitsbergen archipelago and its continental shelf', and that the recommendations of the Commission should be without prejudice to 'the provisions of the Treaty concerning Spitsbergen of 1920 and, accordingly, to the regime of maritime areas adjacent to Spitsbergen.' 16

On 27 June 2002, the Commission adopted its recommendations concerning the submission made by Russia in 2001. The Commission agreed to and recommended the outer limits in the Barents Seas as submitted by Russia. As regards the Central Arctic Ocean, the Commission recommended that Russia make a revised submission. ${ }^{17}$ This implied that at the time Norway made its submission in 2006, the Loop Hole in the Barents Sea was already recommended as continental shelf area, while the area in the Nansen Basin was pending the outcome of the submission by Norway and the revised submission of Russia (See Figure 4.2).

After the Commission adopted its recommendations concerning the Norwegian submission in 2009, Norway and Russia also moved towards a final agreement in their delimitation negotiations. After 40 years of negotiations, the two states reached a maritime delimitation agreement that was signed in Murmansk on 15 September 2010 and entered into force on 7 July 2011. The agreed delimitation line extends to a point north of the outer limit as recommended by the Commission in order to accommodate a possible intersection with the future outer limit of the continental shelf of Russia.

\footnotetext{
15 Document available at: $<$ http://www.un.org/Depts/los/clcs_new/submissions_files/ruso1/ CLCS_01_2001_LOS_NORtext.pdf >.

16 Document available at: http://www.un.org/Depts/los/clcs_new/submissions_files/noro6/ rus_07_00325.pdf>.

17 Reports of the Secretary-General: A/57/57/Add. 1, paras 38-41, https://documents-dds-ny .un.org/doc/UNDOC/GEN/No2/629/28/PDF/No262928.pdf?OpenElement.
} 


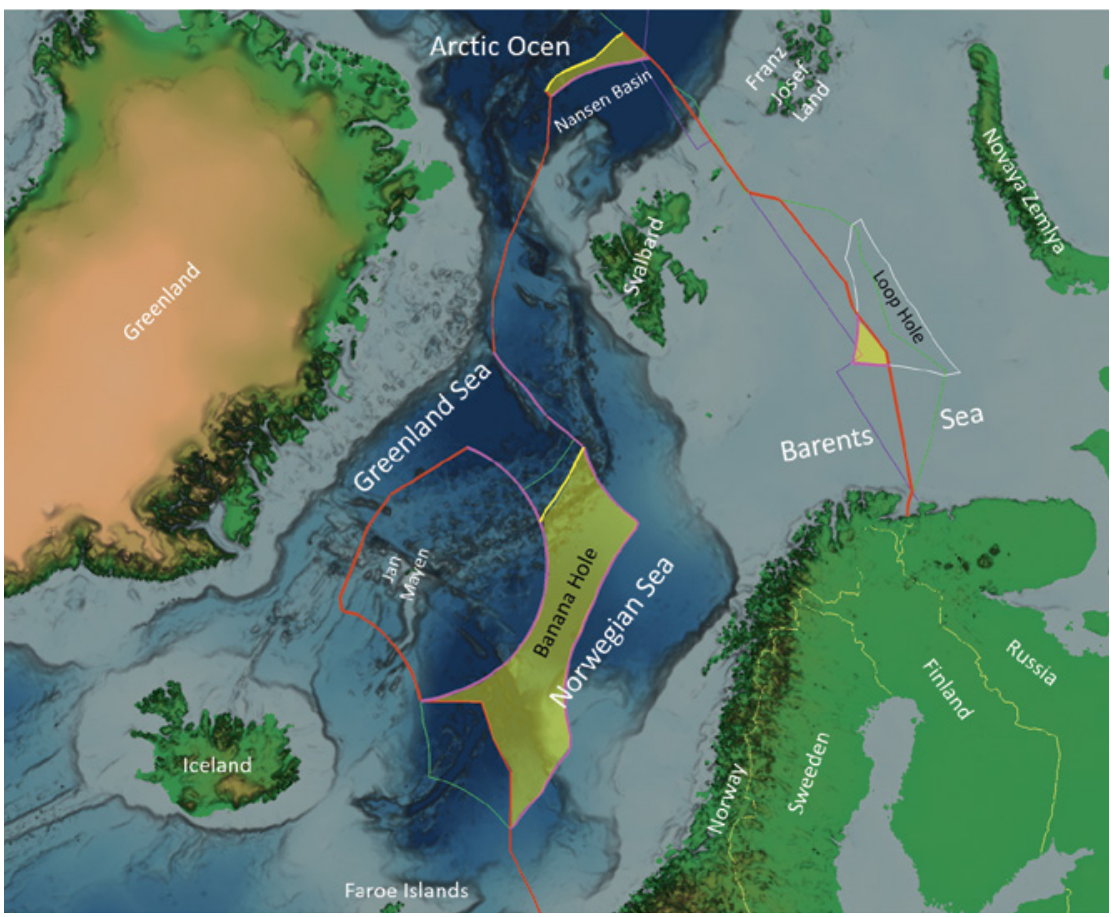

FIGURE 4.2 The continental shelf of Norway in the Arctic Ocean, Barents Sea and the Norwegian Sea. Red lines - agreed maritime delimitation with neighbour states, including the Agreed Minutes with Iceland and Denmark with Faroe Islands. Pink lines - 200 nautical mile lines of Norway. Yellow lines - outer limits of the continental shelf beyond 200 nautical miles as recommended for Norway by the Commission, but yet to be concluded by bilateral delimitation pending the future recommendations for Russia in the Arctic Ocean and Denmark with Greenland in the Norwegian Sea and the Arctic Ocean. The areas of continental shelf beyond 200 nautical miles are highlighted as yellow polygons. Thin green lines - outer limits of the continental shelf of Norway as originally submitted to the Commission by Norway in 2006. Thin purple line western limit of the continental shelf of Russia in the Barents as submitted by Russia in 2001. Thin white line - delineation of the Russian part of the enclave of area beyond 200 nautical miles in the Barents Sea (the 'Loop Hole').

THE NORWEGIAN PETROLEUM DIRECTORATE

\subsection{Relationship with Denmark with Greenland}

On 20 February 2006, Norway and Denmark with Greenland signed an agreement concerning the delimitation of the continental shelf in the area between Greenland and Svalbard. ${ }^{18}$ Upon the submission made by Norway to the

18 Document available at: $<$ https://treaties.un.org/Pages/showDetails.aspx?objid=08000002 80064a71>. 
Commission later the same year, Denmark with Greenland submitted a note verbale of non-objection. ${ }^{19}$

At that time, the states anticipated a slight potential overlap of continental shelf areas in the northern border zone of the Banana Hole. Such overlap was confirmed in the submission made by Denmark with Greenland 26 November 2013. In 2006, no overlap of the continental shelf areas was foreseen in the Nansen Basin. However, at the time of the submission made by Denmark with Greenland in the Arctic Ocean on 15 December 2014, it turned out to be a substantial potential overlap with the continental shelf area of Norway already recommended by the Commission in this region. Norway issued notes verbale of non-objection on both of these occasions. ${ }^{20}$

\subsection{Relationship with Iceland and Denmark with the Faroe Islands}

During the preparation of their submissions in respect of the Banana Hole, Norway, Iceland and Denmark with the Faroe Islands developed the shared view that the whole area concerned consists of continuous continental shelf. It also became clear that there would be potential overlaps of continental shelf areas of the three states in this region, and that Norway would be the first state in position to make its submission to the Commission, while the two others would submit some years later. On this basis, Iceland and Denmark with the Faroe Islands approached Norway and proposed to discuss a possible future delimitation in the area before Norway lodged its submission. The Agreed Minutes that came out of these discussions were published on 21 September 2006. ${ }^{21}$ These minutes include a Model Agreement and the coordinates for the points on which the future delimitations would be based. The final delimitation would be concluded at the time when all three states had received their recommendations from the Commission.

Iceland and Denmark with the Faroe Islands both made their submissions with respect to this area on 29 April 2009. In accordance with the Agreed Minutes all three states issued notes of non-objection with regard to

19 Document available at: <http://www.un.org/Depts/los/clcs_new/submissions_files/ noro6/dnk07_00218.pdf >.

20 Documents available at: <http://www.un.org/Depts/los/clcs_new/submissions_files/ dnk68_13/2014_01_21_NOR_NV_UN_oo1_14-ooo6oo.pdf >, and <http://www.un.org/Depts/ los/clcs_new/submissions_files/dnk76_14/2014_12_17_nor_nv_dnk4_001.pdf >.

21 Document available at: <https://www.regjeringen.no/en/dokumenter/Agreed-Minutes/ $\operatorname{id} 446839 / ? \mathrm{q}=$ Agreed minutes $>$. 
each other's submissions. ${ }^{22}$ The Commission adopted its recommendations for Denmark with the Faroe Islands, and Iceland in respect of this area on 11 March 2014 and 10 March 2016, respectively. Accordingly, the three states have now moved on to conclude their bilateral delimitation as agreed.

\subsection{The South Atlantic Ocean}

The outer limits of the continental shelf appurtenant to the Bouvet Island borders in its entirety with the international seabed, i.e. the Area. The submission made by Norway to the Commission in respect of the Bouvet Island of 4 May 2009, including its revision of 21 May 2015, did not attract any notes verbale from other states.

\subsection{The Southern Ocean}

In its submission of 4 May 2009, Norway noted that appurtenant to Antarctica there exist areas of continental shelf that has yet to be defined. In this context, Norway referred to two ways in which a submission in respect of such areas of continental shelf may be made:

- States concerned may submit information to the Commission, which would not be examined for the time being, or

- make a partial submission not including such areas of continental shelf, for which a submission may be made later, notwithstanding the provisions regarding the ten-year period established by article 4 of Annex II to the Convention. ${ }^{23}$

The outer limits of the continental shelf appurtenant to Dronning Maud Land on the Antarctic Continent as submitted by Norway are located entirely within the area of the Antarctic Treaty System. Consistent with the first option, Norway requested the Commission not to take any action for the time being with regard to this area. ${ }^{24}$ Among the other claimant states in Antarctica, Australia and Argentina also referred to this option, ${ }^{25}$ while United Kingdom,

22 Document available at: <http://www.un.org/Depts/los/clcs_new/commission_submissi ons.htm>.

23 http://www.un.org/Depts/los/clcs_new/submissions_files/nor3o_o9/nor2oog_exe cutivesummary.pdf.

24 http://www.un.org/Depts/los/clcs_new/submissions_files/nor3o_og/nor20o9_exe cutivesummary.pdf.

25 http://www.un.org/Depts/los/clcs_new/submissions_files/auso4/Documents/aus_doc_ es_attachment.pdf, http://www.un.org/Depts/los/clcs_new/submissions_files/arg25_og/ arg_note_20ogeng.pdf. 
New Zealand and France referred to the second option. ${ }^{26}$ Chile has announced that it will inform the Commission on this matter in due course. ${ }^{2728}$

The submission by Norway attracted notes verbale from five states: USA, Russia, India, Netherlands and Japan, all of which confirmed that they do not recognize any State's claim to territory in Antarctica and that they acknowledged Norway's request to the Commission not to take any action on its submission concerning this area. ${ }^{29}$

\section{$6 \quad$ Resources from the Seabed of the Continental Shelf}

According to Article 77 of the Convention, the coastal state has the right to exploit the resources of the continental shelf, specified as the resources of the seabed and the subsoil thereof. These include the conventional geological resources as oil, gas and metallic seabed minerals, as well as biological resources in the form of sedentary species living on or within the seabed. As regards the Norwegian continental shelf, its oil and gas resources are located almost entirely within the 200 nautical miles limits. Establishing the outer limits in accordance the recommendations of the Commission, implies the inclusion of possible oil and gas resources only in the area of the Loop Hole in the Barents Sea and in some minor areas along the 200 nautical miles limits of the Banana Hole in the Norwegian Sea (Figure 4.3). The latter areas are in relatively deep waters and in part strongly invaded by subsurface magmatic rocks of low resource potential.

The areas of continental shelf beyond $200 \mathrm{~nm}$ in the Nansen Basin and in the Banana Hole consist mainly of deep ocean floor with no potential for oil and gas. These areas, however, have a good potential for metallic seabed minerals, namely polymetallic sulphides and polymetallic manganese crusts. Such

26 http://www.un.org/Depts/los/clcs_new/submissions_files/gbro8/gbr_nv_9may2008 .pdf, http://www.un.org/Depts/los/clcs_new/submissions_files/nzlo6/nzl_doc_es_attach ment.pdf, http://www.un.org/Depts/los/clcs_new/submissions_files/fraog/fra_note_feb2 ooge.pdf.

27 http://www.un.org/Depts/los/clcs_new/submissions_files/preliminary/chl2oognot e_e.pdf.

28 H. Brekke, 'Defining and recognizing the outer limits of the continental shelf in the polar regions', in R.C. Powell and K. Dodds (eds) Polar Geopolitics? Knowledges, Resources and Legal Regimes (Edward Elgar Publishing Ltd., Cheltenham, UK, 2014), pp. 38-54.

29 http://www.un.org/Depts/los/clcs_new/submissions_files/submission_nor_30_2009 .htm, https://documents-dds-ny.un.org/doc/UNDOC/GEN/N1o/337/97/PDF/N1033797.pd f?OpenElement. 


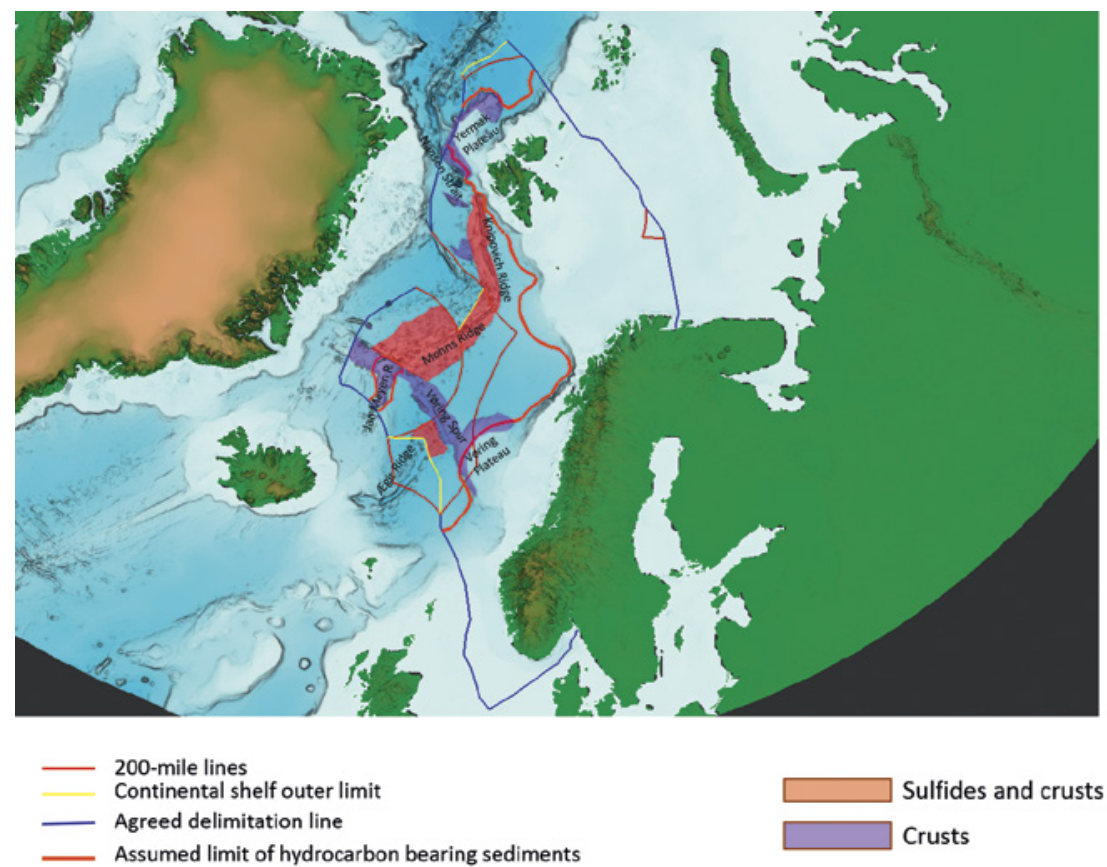

FIGURE 4.3 Map showing the possible distribution of petroleum and mineral resources of the Norwegian continental shelf

THE NORWEGIAN PETROLEUM DIRECTORATE

minerals are already discovered in the deep ocean areas of the Norwegian and Greenland Seas, both within and beyond 200 nautical miles (Figure 4.3). More knowledge about their distribution, volume or exploitability is needed for management purposes and estimation of their economic value.

The known biological resources of the continental shelf, like crustaceans and shellfish, are all associated with the shallow shelf areas, at depths down to 100-400 meters. All of these areas, except for the Loop Hole, are within the 200 nautical mile limits. The biology of the seabed of the deep ocean areas of the continental shelf is much less known. Current scientific research on the deep ocean seabed in the Norwegian Sea, however, has revealed the existence of a benthic fauna that may become an economic genetic resource in the future.

The seabed of the continental shelf around the Bouvet Island consists of magmatic rocks and thin sedimentary cover that cannot host oil or gas. There is a potential for mineral resources in this area, while the potential for biological resources is unknown. 